\title{
Prevalence of metabolic syndrome and its associated factors in Chinese patients with ankylosing spondylitis [Corrigendum]
}

Liu M, Huang Y, Huang Z, et al. Diabetes Metab Syndr

Obes. 2019;12:477-484.

On page 478, Under Patients and methods section, Clinical evaluation and laboratory tests subheading, the sentence should read from "According to the latest Chinese overweight/obesity medical nutrition treatment expert consensus (2016), ${ }^{16}$ overweight is defined as $24 \mathrm{~kg} / \mathrm{m}^{2} \leq$ BMI $\square 28 \mathrm{~kg} / \mathrm{m}^{2}$ and obesity is defined as BMI $\geq 28 \mathrm{~kg} / \mathrm{m}^{2}$." to "According to the latest Chinese overweight/obesity medical nutrition treatment expert consensus (2016), ${ }^{16}$ overweight is defined as $24 \mathrm{~kg} / \mathrm{m}^{2}$ $\leq$ BMI $<28 \mathrm{~kg} / \mathrm{m}^{2}$ and obesity is defined as BMI $\geq 28 \mathrm{~kg} / \mathrm{m}^{2}$."

The correct correspondence address should read as follows:

Department of Rheumatology and Immunology, Guangdong Second Provincial General Hospital, No 466 Xingangzhong Road, Haizhu District, Guangzhou, Guangdong 510317, People's Republic of China.

\section{Publish your work in this journal}

Diabetes, Metabolic Syndrome and Obesity: Targets and Therapy is an international, peer-reviewed open-access journal committed to the rapid publication of the latest laboratory and clinical findings in the fields of diabetes, metabolic syndrome and obesity research. Original research, review, case reports, hypothesis formation, expert opinion and commentaries are all considered for publication. The manuscript management system is completely online and includes a very quick and fair peer-review system, which is all easy to use. Visit $\mathrm{http}: / /$ www.dovepress.com/testimonials.php to read real quotes from published authors. 